\title{
Mit, Destan ve Halk Hikâyelerinde Birinci Dereceden Kahramanların Statüleri Üzerine Bir İnceleme
}

\author{
DR. ÖĞR. ÜYESİ AYSUN DURSUN*
}

Öz

Halk anlatıları bir toplumun inanışlarını, geleneklerini, hayata bakışını yansıtır. Sözlü kültür döneminin en önemli kaynakları olan bu anlatılar, geçmişten günümüze toplumun değerleri ve toplumsal kabulleriyle şekillenmişlerdir. Anlatılarda yer alan kahramanların konumlandırılışı, statülerinin belirlenişi bu değer ve kabullerin sonucudur. Mitlerde kutsal bir öykünün kahramanı, destanlarda olağanüstü güç ve becerilerle yiğitlik sergilerken halk hikâyelerinde gerçek dünyanın yaşam şartlarına uyum sağlayan kahramanlara dönüşmüştür.

Statü, kahramanın metnin içindeki durum veya konumunu belirler. Kahramanın özellikleri bu konum veya durum etrafında halkın hayata bakışını anlamlandırmaya yardımcı olurken, anlatılar aracılığıyla kültürel oluşumların ve halk inanışlarının somutlaştırılması söz konusu olur.

Bu makalede mitlerde, destanlarda ve halk hikâyelerinde bulunan birinci dereceden kahramanların anlatı içindeki konumu ve durumu dikkate alınarak statüleri belirlenmeye çalışılmıştır. Bu çerçevede sıralanan halk edebiyatı türlerinden her biri için üç örnek seçilmiştir. Mitlerde üç tanrı kahraman; destanlarda, çoğu zaman adlarını destana veren birer yönetici kahraman; halk hikâyelerinde erkek kahraman, kadın kahraman ve kahramanların aileleri olmak üzere üçer kahraman statü yönünden incelenmiştir.

Anahtar sözcükler: Mit, destan, halk hikâyesi, kahraman, statü.

\section{AN ANALYSIS ON THE STATUS OF FIRST DEGREE HEROES IN MYTH, EPIC AND FOLK STORIES}

\section{Abstract}

Folk narratives reflect a society's beliefs, traditions, world-view. From past to now, these narratives which are very important sources of oral culture period have been shaped by the values of society and social acceptance. The position of heroes which takes place in a narrative, the determination of their status is the result of these value and acceptance. When

\footnotetext{
* Muğla S. K. Üniversitesi Edebiyat Fakültesi TDE, orcid.org/0000-0002-1614-3618, adursun@mu.edu.tr Gönderim tarihi: 18.05.2018

Kabul tarihi: 20.06.2018
} 
the hero of a sacred story in myths displays bravery with extraordinary power and abilities in epics, s/he transforms to the heroes who are adaptable to the life conditions of real world in folk stories.

Status defines the position or situation of hero in a text. Around this position or situation, the features of hero both contributes to improve folk's explanations/interpretations about life, and embody the cultural formation and folk beliefs by narratives.

In this article, the status of first degree heroes in myths, epics and folk stories had been analyzed by taking into consideration their position and situation in the narrative. In this frame, three example for each of concatenated folk literature types had been chosen. Three God heroes in myths; executive heroes who usually give their names to narratives in epics; three heroes as male hero, female hero and the families of heroes in folk stories had been scrutinized in terms of status.

Keywords: Myth, epic, folk story, hero, status.

\section{Gírìs}

Пoplumların sözlü kültür döneminin taşıyıcıları olan mitik anlatılar, destanlar ve halk hikâyeleri; kahramanları, zamanı, mekânı, sosyal çevreyi ve

L kahramanı kahraman yapan koşulları dünyayı çözümleme ve anlamlandırma çabası içinde geçmişten günümüze aktarmışlardır.

İnanç temelli anlatılar arasında yer alan mitler, destanlarda yerini olağanüstülüğe, halk hikâyelerinde ise daha çok gerçekliğe bırakır. Kutsallıktan gerçekliğe geçen bu süreçte kahramanlar da çeşitli özellikleriyle dönüşümler ve değişimler yaşar. Kahramanların anlatı alanında toplum içindeki durumları, statüleri değişir.

Statü, bir kimsenin, bir kurum veya bir toplum içindeki konumunu, kadro bakımından bağlı olduğu durumu (Türkçe Sözlük, 2005, s. 1809), toplumsal hiyerarşide somutlaşan, hak ve sorumluluk bakımından farklılık gösteren yerini ifade etmektedir (Demir ve Akar, 2005, s. 381). Bir başka ifadeyle statü grupları veya katmanlarının hukuksal, siyasal ve kültürel ölçütlerle derecelendirilip düzenlendiği bir toplumsal tabakalaşma biçimidir (Marshall, 1999, s. 697-698).

Bir toplumda yaşayan her birey, kimi zaman varoluşsal kimi zaman da neden sonuç ilişkileri bağlamında toplumda kendine ait bir yer bulur. Bu konumu yükseltecek şartlar toplumların hayata bakış açılarıyla doğru orantılıdır. Sosyal nosyonlarla birleşen kültürel unsurlar, inanç, aile yapısı, eğitim durumu ve düzeyi, meslek grupları vb. gibi değişkenlere bağlı olarak bireylerin toplumda bir statü kazanmasına zemin hazırlar.

Toplumların yaşamı algılama ve anlamlandırma çabasının yansımaları, mitik anlatılar aracılığıyla günümüze taşınmıştır. İnsanlık âlemi, gücünün yetmediği, kimi zaman da 
açıklayamadığı olaylar karşısında düştüğü çaresizliği kendinden daha kuvvetli gördüğü varlıklara atfederek bu çaresizliği ortadan kaldırmaya çalışmıştır. Pek çok inanç sisteminde yaratıcı güce sahip olan Tanrı, güçlü ve yücedir. Konumu daima en yüksek mevkidir.

Evrenin kuruluşu ve temellendirilmesi bakımından Tanrı'nın önemi büyüktür. Bu süreçte pek çok mitik anlatıda Tanrı, ezeli ve ebedi olmak, evreni oluşturmak, düzenlemek, yönetmek görevlerini yerine getirebilecek güce sahip olmak, insanların yaratılması, görevlendirilmesi, hayatlarının düzenlenmesi, ölüm sonrasındaki durumu belirlemek gibi konuların belirleyicisi konumundadır (Bıçak, 2012, s. 49). Eski dünya düzeninde hemen hemen tüm inanışlarda evreni yaratan, gönderdiği yağmurlarla toprağa bereket veren sonsuz bilgeliğe ve ayrıcalığa sahip olan göksel bir varlıktan bahsedilir. Bu varlık kabilenin ahlak kurallarını, ritüellerini belirlemiş, kurallara uymayanları yıldırımlarını göndererek cezalandırmıştır. Kutsal ve güçlü varlığın mekânı kabul edilen gök, aşkınlığın ve sonsuzluğun simgesidir. Statü bakımından en yüksek olmak, doğal olarak Tanrılara özgüdür. Bu türden Tanrısal bölgelere ayrıcalıklı kişiler, göğe yükselme ayiniyle ulaşırlar. Yüksek, insanların ulaşamayacağı bir boyuttur. Göğü mesken tutanlar, insanüstü güçlere ve varlıklara sahiptirler. Yüce olmak, yüksekte bulunmak güçlü ve kutsal olmakla eş değerde kabul edilir (Eliade, 2014, s. 61-62). Eski Türklerde hakanları tahta çıkaran, Türklere zafer kazandıran, felaketlerden koruyan Gök Tanrıdır (İnan, 2006, s. 26). Bir hükümdar için tanrı soylu olmak, simgesel anlamda dünyadaki en büyük yönetici olmak anlamına geldiğinden bu güce sahip olmak isteyen hükümdar, kutsalın gücünü kullanarak dünyadaki erkini sağlam bir hanedanlığa dönüştürme çabasındadır (Önal, 2009, s. 59). Sözlü kültür anlatılarından hareketle özellikle mitik metinlerde bu durumun izlerine sıkça rastlanmaktadır. Hükümdar, tanrı soylu olmakla alt edilemez bir güce sahip olduğunu bildirmektedir. İnanç kodlarıyla birleşen bu güç, statü olarak herhangi bir kişinin erişemeyeceği bir konumu işaret etmektedir.

Evrenin gök, yeryüzü ve yer altı olmak üzere üç katmandan oluştuğu düşünülmüştür. Tanrıların mekânı olan gök, en yüksek değere sahiptir. İnsanların yaşadığı alan yeryüzüdür. Yeryüzündeki faaliyetler 'gök'ün kontrolündedir. Yer altı ise kötü yaratıklar ve ölüler dünyasıdır (Bıçak, 2012, s. 83). Mitlerde genellikle yaşadığı mekân gökyüzü olarak belirlenen birinci dereceden kahramanların, destanlarda kimi zaman gökyüzünde kimi zaman yeryüzünde, halk hikâyelerindeki kahramanların ise yeryüzünde kendilerine bir yer buldukları söylenebilir.

$\mathrm{Bu}$ çerçevede birinci dereceden kahramanların mitik anlatılardaki statülerini belirleyebilmek için Türk, Yunan, Misır mitleri, destan metinlerindeki statüleri belirleyebilmek için Oğuz Kağan, Gılgamış, Manas destanları ve halk hikâyelerindeki 
kahramanların statülerini belirleyebilmek için Kerem ile Aslı, Tahir ile Zühre, Ferhat ile Şirin hikâyeleri incelenmiştir.

\section{MIT KAVRAMI}

Mitos (mythos), Yunancada söz, öykü anlamına gelir. Mitoslar, arkaik insan topluluklarının evreni, dünyayı ve doğa olaylarını kişileştirerek yorumlamak, henüz sırrını çözemedikleri yaşamın ve evrenin çeşitli görüntülerini bir anlam kolaylığına bağlamak gereksiniminden doğmuş öykülerdir (Necatigil, 2002, s. 13). M. Eliade'ye göre, "mit" kutsal bir öyküyü, en eski zamanlarda başlangıçtaki masallara özgü zamanlarda olmuş bitmiş olayları, bir şeyin nasıl yaratıldığını, nasıl var olmaya başladığını anlatır. Gerçekten olmuş bitmiş tam anlamıyla ortaya çıkmış olan şeylerden söz eder, yaratıcı etkinliği ortaya koyar ve kutsallığı gözler önüne serer (Eliade, 1993, s. 13). Mit; uydurma, kurgulama bir hikâye değil, arkaik toplumların gerçek olduğuna inanılan kutsal hikâyeleridir. İnsan, miti bilmekle nesnelerin kökenlerini de bilmiş olur. Böylece o nesneleri

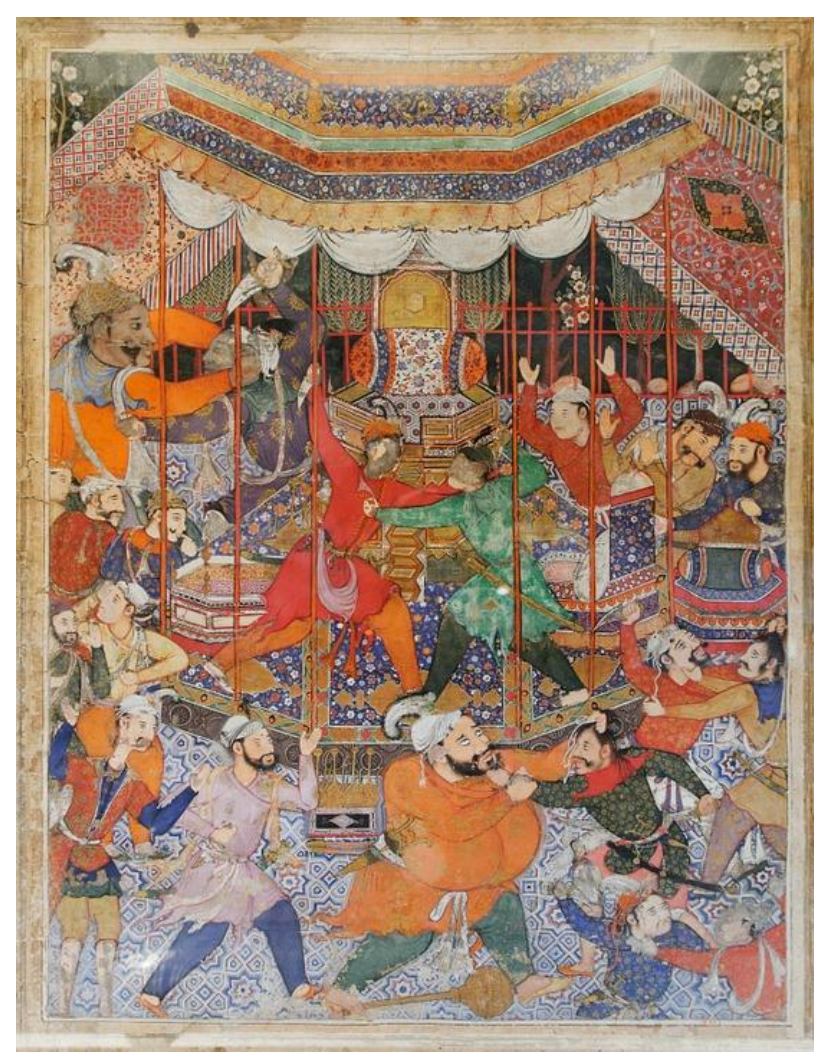
yönlendirmek veya ona egemen olmak isteyen insanlar, onların öyküsünü bilmek zorundadırlar. Burada dıştan bir bilgi değil, yaşanan bir bilgi söz konusudur. İnsan, miti bir şekilde yeniden hatırlar ve yeniden gerçekleşme aşamasında olayları kutsal ve coşku verici gücün etkisiyle bir anlamda yeniden yaşar. Mitsel olayların hatırlanması değil, bunların yenilenmesi söz konusudur (Eliade, 1993, s. 23-24).

Mitlerin yapısını ve işlevlerini anlamak insanların düşünce tarihini anlamak demektir. Mitler, sadece dünyanın, insanların, hayvanların ve bitkilerin kökenini anlatmaz, aynı zamanda insanlık tarihinde olup biten bütün önemli olayları anlatır. Hikâyesi olan yaşar, anlatıma dayalı türler aracılığıyla insanlığın bilgi, deneyim ve yöntemleri gelecek nesillere aktarılır. Bu bağlamda Binbir Gece Masallarında hikâyesi sayesinde yaşama tutunan Şehrazat, hem gerçek hem de mecaz anlamda yerinde bir örnek olacaktır.

Mitler genellikle tanrıları ve doğaüstü varlıkları kahraman olarak merkeze alır. Ancak kimi mitik anlatılarda insan kahramanların ön plana çıktığını söylemek de mümkündür. Hint mitlerinde Rama, ruhanî varlığına rağmen insani özellikleri bünyesinde barındıran bir kahramandir. 


\section{MİTIK KAHRAMANLARIN STATÜLERI / TANRI KAHRAMANLARIN}

STATÜSÜ

\section{A. Türk Mitlerinde Kahramanın Statüsü}

Dünyanın yaratılışı, yeryüzü şekillerinin ortaya çıkışı ile ilgili pek çok soruya cevap veren mitler; Türk mitik anlatılarında da bu özelliğini korumuştur. Seçilen üç tanrının (Ka(y)ra Han, Erlik Han, Umay Ana) statüsü bu bağlamda belirlenmiştir.

\section{Ka(y)ra Han}

Yerin yer olduğunda, her yer sularla kaplıyken sadece tanrı vardır ve hep göklerde uçar. Hiçbir zaman yorulmaz. Çünkü konacak yer yoktur ve o tanrıların babasıdır. Hiçbir şey yokken de var olan Ka(y)ra Han, her şeyin yaratıcısı, merhametli ve iyi yürekli bir tanrıdır. Yarattığı her varlık bir iyilik düşüncesinden türemedir. 'Ak ine"den aldığı ilhamla bütün varlıkları yaratmıştır (Çoruhlu, 2010, s. 44). Ka(y)ra Han yarattı̆ğ yerin ortasında dokuz elli bir çam ağacı, her dalı altında da bir adam yaratmıştır. Bu adamlar insanların atalarıdır. Ülgen, Kızagan ve Mergen adında üç oğlu vardır. Dürüst ve adaletli aynı zamanda koruyucudur. Onun emrine bakan bir ulusu vardır (Ögel, 1993, s. 451-465; Uraz, 1994, s. 62).

Ka(y)ra Han, mekânı yüceltilmiş gökyüzü olan, her şeye gücü yeten, yaratıcı, bilge, insani zayıflıklar göstermeyen, güçlü, cesaretli, sabırlı ve erdemli bir Tanrıdır. Cesaret gücü, sabır ve erdem yüceliği, yücelikte kutsallığı beraberinde getirmiştir. Onun bu özellikleri insanların zihninde her şeye gücü yeten, üstün ve tüm olumlu özellikleri kendinde toplayan bir varlık olarak en üst seviyede konumlandırılmasına zemin hazırlamıştır.

\section{Erlik Han}

İlkel büyük tanrıların bazıları cisimsizdir. Sadece adları bilinir, görünmezler, büyük bir gücü ellerinde tutarlar. Ancak bazı tanrılar cisimlendirilmiştir ve Erlik de bu cisimlendirilmiş tanrılardan biridir. İnsan kılığında gözüken ‘antropomorf tanrı'lardandır. İnsanlarla ilişkileri diğer tanrılara göre fazladır (Uraz, 1994, s. 45, 47).

Yeraltına mensup kötü ilah veya ruhların başında şeytana karşılık gelen Erlik bulunmaktadır. Erlik, her çeşit hastalığı insanlara musallat ederek onlardan kurban ister. Bu kurbanlar verilmediği takdirde öldürdüğü insanların canlarını yakarak yeraltı dünyasında köle olarak çalıştırır. Şaman dualarında bir canavar olarak tasvir edilen Erlik, sağlam vücutlu bir ihtiyar olarak kabul edilir. Saçları, kaşları ve gözleri siyah ve kıvırcık, çatal şeklinde uzamış sakalı olan, yaban domuzuna benzeyen azı dişli, yılan kamçılı ve kara renkli bir ata veya öküze binen Erlik'in bazı yerlerde demirden kılıcı ve kalkanı ile tasvir edildiği bilinir (Çoruhlu, 2010, s. 54).

Erlik Han, yerin altında kara bir güneş yaratarak o güneşin kara ışığı ile yerin altını aydınlatmıştır. Yeraltında bir sarayı vardır damı demirden, ocağı balçıktan yapılmıştır. Bu 
sarayın kapısında gümüşten bir tahtı bulunmaktadır. Kılıcı ve kalkanı demirden yapılmıştır. Dokuz boğa eyerlenmiş bir şekilde onun emrinde bulunmaktadır. Yerin altında oturan Erlik Han, kardeşi Ülgen'e hiç benzemez. Ka(y)ra Han'ın oğlu olmasına rağmen emrinde bulunan ikinci derecedeki kötülük tanrıları ve ruhlarıyla insanlara kötülük yapar ve bu kötü işler onu mutlu kılar. Oysaki kendi oğulları da iyi tanrılardır. Bütün kötü ruhlar onun idaresi altındadır. Erlik'in beş oğlu, iki kızı vardır. Yaşadığı âlem dokuz tabakaya ayrılmıştır. Bu tabakaların her birinde kötü ruhların temsilcisi olan birer tanrı vardır ve o tanrılar da Erlik'in idaresindedir. İnsanlar, Erlik'ten ve Erlik'in gazabından korkarlar, bu gazaptan korunmak için kurban keserler (Uraz, 1994, s. 58-59). Çünkü Erlik kıskançtır. Ka(y)ra Han'ın sahip olduklarına o da sahip olmak ister. Bir han olmasına rağmen tatminsizdir, daha fazlasını ister. Bu yüzden Ka(y)ra Han'a karşı çıkar ve insanları doğruluktan ve iyilikten ayırmak için elinden geleni yapar (Ögel, 1993, s. 451-465).

Erlik Han, fiziki özellikleri bilinen, tasvir edilebilen cisimlendirilmiş bir tanrı olarak mitik anlatılarda yer almaktadır. Söz konusu fiziki özellikleri ile bile kötü ve aşağı olan yeraltına ait bir varlık olarak görüldüğü anlaşılmaktadır. Sahip olduğu kara sıfatıyla bir kez daha alçaltılır. Kötülüğün ve hilekârlığın sembolik ifadesi olur. Saygınlık ve yücelik bakımından halkın zihnindeki konumlandırılışı yerin altıdır. Halk arasında sıkça kullanılan "yere batasıca", "yerin dibine giresice" gibi beddualar Erlik'e ve ona ait olan kötü, olumsuz dünyaya gönderilmek istenen kişiye verilecek en büyük ceza olarak görülür. Bu bakış açısı Erlik'in halkın algısındaki yerine ve dolayısıyla statüsüne işaret eder.

\section{Umay Ana}

Etene ve doğurganlık tanrıçası olan Umay, itibar sahibidir ve toplumda saygın bir yeri vardır. İmparatoriçe (Hatun) diye adlandırılır. Bütün hükümdarların karısı ona benzemektedir. Kutunu, Umay'dan alan "Hatun" onun yardımıla çocuğunu dünyaya getirir (Çoruhlu, 2010, s. 39). Gök ile bir görülür. Bu onun saygınlığını arttırır (Bonnefoy, 2000, s. 1102).

Çocukları ve hayvan yavrularını gözeten, koruyan büyük bir tanrıçadır (Uraz, 1994, s. 81). Umay genellikle çocuklarla beraberdir ancak kimi zaman onları terk eder, bu durumda çocuk hastalanır. Kırgızlarda Umay, aynı zamanda bol ürün almaya, mal mülkün artmasına da yardım eder. Devleti ve hâkimiyeti koruyan bir ilahe olan Ötüken ve onun kültüyle ilişkilendirilen Umay, korumacılık vasıflarıyla benzerlik gösterir. Güneşle ve güneşin isı vermesinden hareketle ateş ve ocak kültüyle de bağı vardır (Çoruhlu, 2010, s. 41).

Soy devamlılığının âdeta sembolü olan ateş ve ocak kültüyle birleştirilen Umay Ana, neslin sürekliliğinin sağlanmasına yardım ettiğinden toplum tarafından benimsenmiş ve büyük itibar görmüştür. Gerçek dünyanın zorluklarıyla baş edemeyecek durumda olan yeni nesilleri koruması Türk toplumunun değer yargılarına uygun olarak Umay Ana'ya statü 
bakımından ayrıcalık getirmiş ve saygın bir yer kazandırmıştır. Türkiye'nin pek çok şehrinde kötü ruhların yeni doğan bebeğe ve annesine zarar vereceği inancıyla lohusa kadın ile bebek yalnız bırakılmaz, çeşitli nesneleri kullanarak ve uygulamalar yaparak korunurlar. Burada kadınların ve çocukların koruyucu ruhu olarak Umay Ana görülmektedir.

\section{B. Yunan Mitlerinde Kahramanın Statüsü}

İnsani özelliklerin ön plana çıktığı Yunan mitlerinde, Tanrı ve Tanrıçalar olağanüstü güç ve nitelikleri olmakla beraber insana ait görülen pek çok duygu ve davranışı anlatılarda sergilemektedir. Bu bağlamda çalışmada Zeus, Hera ve Aphrodite statüleri açısından değerlendirmeye tabi tutulmuştur.

\section{Zeus}

Rheina ile Kronos'un oğludur. Egemenliğini bir çekiliş sonucu elde eder. Bu çekilişte ona gökler çıkmıştır. Zeus çok eşlidir, farklı kadınlardan birçok çocuğu vardır. Zeus'un her zaman çok akıllı ve kuvvetli olduğu söylenemez. Onun insana özgü pek çok yönü vardır, bu zaafları Hera'yı çok kızdırır. Zeus dünyadaki düzenin bir koruyucusu olarak yapılan anlaşmaları gözetip yabancıları ve ondan yardım isteyenleri koruyarak yapılan bütün iyi ve kötü işleri bağışlar (Fink, 1997, s. 332-336).

Zeus, Tanrıların tanrısı, tanrıların babası ve büyügüüür. Tanrıların tanrısı Zeus, göktür, Gök Tanrı'dır, gökle ilgili doğal güçlerin hepsini kişileştiren varlıktır. Işık, aydınlık, bulut, gök gürlemesi, şimşek, yıldırım Zeus'un egemenliği altındadır. Zeus daha ilkel bir evren görüşünde Uranos, Gök Tanrı diye adlandırılan doğanın kendisi değil, doğayı insan düzenine benzer bir düzene sokup yönetimini ele alan bir insan Tanrıdır. Bütün krallar Zeus'tan doğma ve yetişmedir (Erhat, 2003, s. 293-297). Zeus'un gücü, bütün tanrıların güçlerinin toplamından büyüktür. Bu demektir ki diğer tanrılar ona itaat etmek zorundadır. Buna rağmen ona karşı koyanlar, onu aldatanlar çıkmıştır. Zeus âşık olur, kadınların peşinden koşar ancak aşk ve kadın yüzünden ululuğu kaybetmemiştir (Hamilton, 2002, s. 12, 14).

Zeus, Troya Savaşı'nın gizli kahramanı bir bakıma da başrol oyuncusudur. Çünkü $O$, İda Dağı'nın tepesi olan Gorgaros Zirvesi'nden savaşı yönetmektedir. O istemeden ve onun buyruğu olmadan hiçbir şey olmaz. Diğer tanrıların buyruklarını insanlara aktarmak işi ise Zeus'un kuşu kartalın görevidir (Erhat, 2003, s. 294). İlyada'da Zeus görülmektedir, eylemleri takip edilebilir. Odysseia'da ise doğrudan doğruya değil ancak bir sunu yapıldığında, dua edildiğinde, ant içildiğinde Zeus'un etkisi görülmektedir. Varlığını kuşu kartalı,

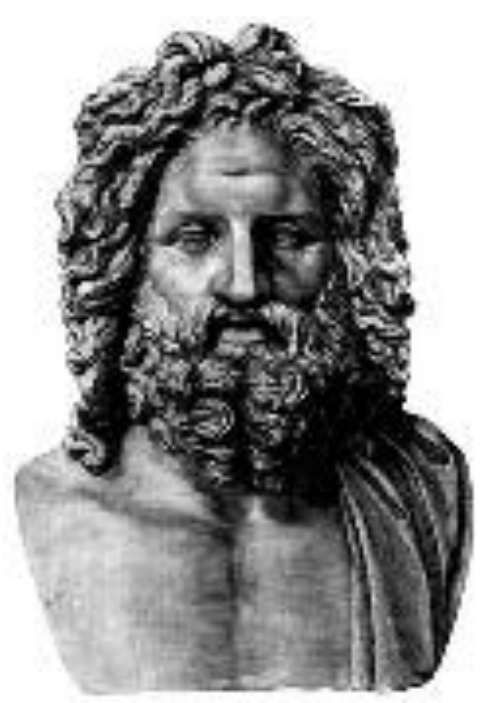


gök gürültüsünü veya şimşeği kullanarak belli eder. Zeus; konuksever, 1lıman, zalimce düşünceleri olmayan, merhametli, hakka dayanan insanca bir düzenin kurucusu ve koruyucusudur. Bazı olaylarda ise Zeus'un üzerinde de bir güç vardır ki o da kaderdir (Erhat, 2003, s. 296).

Silahı yıldırım olan Zeus'un, Ombrios ve Hyettios (yağmurlu), Urios (iyi rüzgarlar gönderen), Astrapios (şimşek gönderen), Bronton (gürleyen), Georgos (çiftçi), Chthonios (yerde oturan) gibi unvanları fırtınayla, yağmurla, üretkenlikle ilgili yönlerini ortaya koyar. Zeus yağmuru kontrol eder, tarlaların bereketini arttırır (Eliade, 2014, s. 95-96). Zeus'un sıfatları Hypsibremetes (göklerde gürleyen), Asteropetes (şimşek savuran), Terpikeraunos (yıldırım seven), Erigdoupos (uzaklardan gürleyen, gök gürültüsü, uzaktan duyulan yankılanan), Aigiokhos (kalkanlı), Kronosoğlu ve Olymposlu soyadı yerine kullanılır. Bu, Zeus'un belli bir kuşaktan ve tanrı soyundan geldiğini gösterir (Erhat, 2003, s. 294).

Pek çok iyi sıfata ve özelliğe sahip olan Zeus, Yunan mitlerinde en büyük Tanrılardan biri olarak kabul edilir. Mekânı gök ve yüksek yerlerdir. İyi özellikleri onu erdemli bir Tanrı olarak gökyüzünde yaşatır. Bununla beraber Zeus'un pek çok insani zayıflığı olduğu yaşam biçiminden anlaşılmaktadır. Zeus, güçlü ve cesur bir Tanrı olmakla birlikte sabırsız ve acelecidir. Bu durum ise sahip olduklarını kimi zaman basit bir şekilde kaybetmesine neden olur.

\section{Hera}

Hera, Kronos ile Rheia'nın kızı, Zeus'un eşidir ve Zeus ile diğer Olympos'lu tanrıların kız kardeşidir. Kendi kocasıyla yatmaktan çekinen, dedikodulardan korkan bir tanrıçadır (Erhat, 2003, s. 136-137). Ares, Hephaistos, Eileithyia ve Hebe'nin annesidir. Roma' da evin ve evliliğin koruyucusu olarak Iuno ile eş tutulur. Tanrısal kocası Zeus'un sayısız kaçamağına çok kızar ve onunla birlikte olanları ve Zeus'un bunlardan olan çocuklarını nefret ve kinle takip eder (Fink, 1997, s. 131). Homeros destanlarında 'inek gözlü', 'ak kollu' veya 'altın tahtlı' diye nitelenen Hera'nın kişiliği ve efsaneleri hep bir kavga, kin, hınç ve geçimsizlik havası yansıtır, sevimsiz bir tanrıçadır. Dırdırcı, kıskanç, hırçın, inatçı, düzen kuran, sevgi ve nefretinin nedeni hiçbir mantığa dayanmayan, silah ve yetkilerini kötüye kullanmaktan çekinmeyen bir tanrıçadır. Bu sıfatların hepsi ona Homeros tarafından yakıştırılmıştır (Erhat, 2003, s. 135). Bununla birlikte Hera, evlilik kurumunun ve evli kadınların koruyucusu olduğundan kendisine büyük itibar gösterilir (Hamilton, 2002, s. 15).

Zeus'un yanında eşi ve ailesinin önemli bir ferdi olarak yaşamını sürdüren ve yüceltilmiş mekânlarda görülen Hera kıskançlık, kızgınlık, hırçınlık gibi insani zayıflıklarına rağmen tıpkı Umay Ana gibi soy devamlılığının ve kadınların koruyucusu kimliğiyle statü bakımından önemli bir konumdadır. 


\section{Aphrodite}

Babası Uranos'tur. Uranos'un Kronos tarafından orakla kesilip denize atılan cinsel organı etrafında oluşan köpükten dünyaya gelmiştir. Bu yüzden “köpükten doğan” olarak anılır (Fink, 1997, s. 49-51). Aşk, Aphrodite ile anılır, onun gerçekleştirdiği en önemli iştir (Yörükan, 2000, s. 22). Aphrodite, hem ölümlülerin hem de ölümsüzlerin akıllarını çelen aşk ve güzellik tanrıçasıdır. Onsuz sevinç de mutluluk da olmaz (Hamilton, 2002, s. 18, 19). Homeros bu Tanrıça'ya Altın Aphrodite derken şairler, Aphrodite'yi güzeller güzeli, işveli, cilveli ve gönül alıcı olarak tanımlarlar. Sevgiyi, aşkı simgeleyen bu tanrıça bu büyüyü kendi kendine değil, çevresinde olan diğer tanrısal varlıkların aracılığıyla gerçekleştirir. Şairlerin ve sanatkârların ilham kaynağı olan Aphrodite'nin öfke anları, öç aldığı zamanlar korku vericidir. $\mathrm{O}$, hiç çekinmeden tanrılarla beraber olur ve onlardan çocuğu dünyaya gelir. (Erhat, 2003, s. 42-44).

Aphrodite'nin olağanüstü doğumu ona, daha dünyaya gelirken ayrıcalıklı bir statü sağlar. Ancak çokeşlilik ve sahip olduğu fiziki özellikleri kötüye kullanması etrafındakileri kızdırır. Ona kin duymalarına neden olur. Çeşitli erdemlere sahip olmayışı, öfkelenmek ve intikam almak gibi insani zayıflıkları ağır bastığından olağanüstü özelliklerine rağmen toplumun zihninde yüksek bir mevkide olduğu söylenemez.

\section{Misır Mitlerinde Kahramanın Statüsü}

Tanrısallığın bir kutsiyet etrafında görüldüğü Mısır mitik anlatılarında kimi zaman bir destan kahramanının kimi zaman da bir hikâye kahramanının özelliklerine yaklaşan bir tip sergilendiği görülmektedir. Bu bağlamda İsis, Osiris ve Horus statüleri bakımından değerlendirilmiştir.

\section{1. İsis}

Thoth, yeşil ürünlerin tanrısı ve ulu tanrıça İsis'in babasıdır. İsis, kral-tanrı Osiris'in kız kardeşi ve aynı zamanda karısı, güneş-tanrı Horus'un da annesidir. Başında ay taşıyan bir inek biçiminde imgelenen İsis, toprak, toprak ürünleri, deniz ve yeraltı ülkesine egemen olup yaşamla ölümü elinde tutan, ayrıca büyü yoluyla doğa güçlerini yöneten bir tanrıçadır (Rosenberg, 1998, s. 244; Erhat, 2003, s. 162). İsis hizmetçilerle konuşur, onların saçlarını örer, onları parfümler (Rosenberg, 1998, s. 246, 247).

İsis, üretim ve tüketim ile yaşam ve ölüm arasındaki ince çizgide statü bakımından oldukça önemli bir yere sahiptir. Başında taşıdığı ay sembolik olarak doğurganlığın ifadesidir. Başka pek çok kültürde kadın ve çocukları koruyan Tanrıçaların dengi konumundadır. Bu durum ona hem bir güç katmış hem de

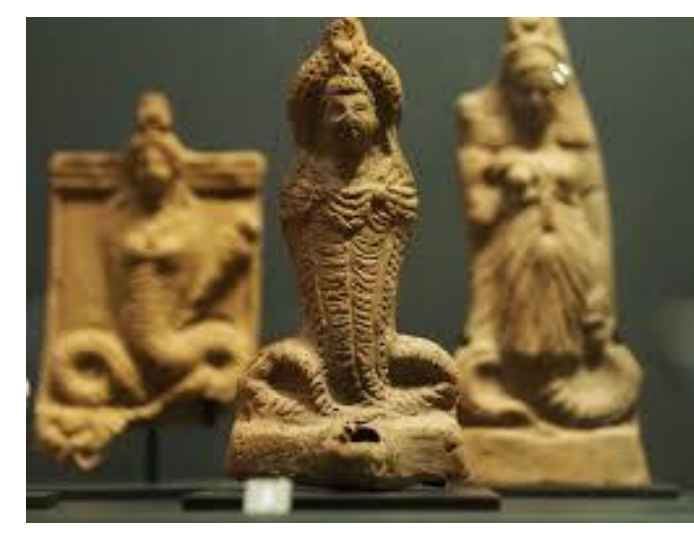


tevazu sahibi bir kişi gibi davranmasını sağlamıştır. İsis bir tanrıça olmasına rağmen kendine göre statü bakımından daha alt konumda görülen hizmetkârlarla vakit geçirip, onlarla ilgilenmiştir.

\section{Osiris}

Osiris'in babası krallık kurumunun tipik simgesi olan tanrı Gebeb'tir. Babası, yetkilerini oğlu Osiris'e bırakır. Osiris, İsis ile evlidir. Osiris dünyaya geldiği zaman her yana "Her şeyin hakimi doğdu" diye bir ses yayılmış ve böylelikle Osiris aşağı ve yukarı Mısır'ın kralı olmuştur. O ideal bir kraldır. Mısır onun döneminde en parlak zamanını yaşamıştır. İlahi ve şarkı söyleyerek, müzikle fikirlerini ifade ederek insanları ikna etmiştir. İnsanlığın iyiliği için çalışmış, topraktan daha iyi ürün alabilmeleri için onlara tarımı, bağcılığı ve çeşitli el sanatlarını öğretmiştir. Kabileler halinde yaşayan halkını birleştirmiş, medeni bir toplum olmalarını sağlamış, barış içinde yaşamaları, çalışmaları için çeşitli kurallar ve kanunlar göndermiştir. Tanrılarına, onların buyruklarına saygı duymayı ve onlara ibadet etmeyi öğretmiştir (Rosenberg, 1998, s. 244; Erhat, 2003, s. 232; Seyidoğlu, 1995, s. 62).

Olağanüstü özelliklere sahip Osiris'in bilgelik ve erdemlilik gibi vasıflara sahip olduğu, dünya düzenini sağlayan pek çok kural ve yöntemi kendi halkına öğretebildiği ve insani pek çok özellik taşıdığ1 görülmektedir. Köken olarak soylu ve kutsal bir aileye mensup olması halkının onun koyduğu kurallara bağlılık göstermesinde etkili olmuştur. Halkın zihninde Osiris, yüksek bir statüye sahiptir.

\section{Horus}

Horus, İsis ve Osiris'in oğludur. Osiris'in ardından Yukarı ve Aşağı Mısır’ın kralı olmuştur. Tıp biliminde çok yetenekli, sağlıklı bir gençtir. Zehirli bir yılan veya en güçlü aslan bile Horus'u öldüremez çünkü $\mathrm{O}$, Re ve İsis tarafından korunmaktadır. İnsandan hayvana dönüşebildiği gibi ölümsüz bir göze de sahiptir. Ölmüş olan babasının tohumlarından doğduğundan, Horus, ölüler ve yaşayanlar arasında bir aracı olarak seçilmiştir. Kadınlar ve erkekler, hayattayken yaptıkları iyi işleri kaydetmesi için Horus'a dua ederler ve ölümden sonra tekrar hayata dönmek için Osiris'e yakarırlardı. Meclisteki tanrılar Horus'u, babası gibi tüm yeryüzünün efendisi olarak kabul ederler. Horus bir kez daha Mısır'da adaleti ve düzeni kurduğundan onun hükümdarlığıyla ülkesine zenginlik geri gelmiştir (Rosenberg, 1998, s. 251, 252).

Adaleti sağlayan bir hükümdar olarak Horus, sağlıklı bir genç olarak tarif edilmiş, kendisine insani özellikler de yüklenmiştir. Bununla birlikte yaşam ile ölüm arasında gidip gelebilen, ölümsüz bir göze ve dönüşüm özelliğine sahip bir tanrı olan Horus, olağanüstü ve tanrısal özellikleriyle de statü bakımından önemli bir yerdedir. Sahip olduğu ölümsüz göz, insanların Horus'a saygı duymalarını sağlar. 


\section{DESTAN KAVRAMI}

Destan kelimesi dilimize, Farsça'da "efsane ve mesel ve hikâyet-i güzeştegân" anlamında kullanılan "dastân" kelimesinden ses ve anlam değişikliği ile girmiştir. Destanlar doğrudan doğruya olmasa bile tarihle bağlantılı yönleri olan, kahramanlık unsurunun ön planda olduğu, olayların daha çok bir şahsın etrafında toplandığı, bir milletin ortak değer ve kabullerini dile getiren, nesilden nesile aktarılarak günümüze taşınmış genellikle manzum olarak görülen bir anlatı türüdür (Yıldız, 1995, s. 3, 5-8).

Bir toplumda, millî kültürü besleyen, geliştiren ve onu biçimlendiren kaynakların önemli bir kısmı o toplumun sanat ve estetik değerlerinde, masallarda, destanlarda halk edebiyatında ve halk biliminin değerler sisteminde mevcuttur. Bir toplumun kültürel değerlerini ve yaşayış biçimlerini ortaya koyan anlatı türleri, o milletin devlet düzenini, siyasi, sosyal, iktisadi yapısını sembolize eder (Türkdoğan, 1999, s. 9-12). Olağanüstü unsurların hâkim olduğu destanlarda kahramanların mücadeleleri ve halkı çeşitli zorluklardan nasıl kurtardıkları konu edilir. Kahramanların mücadele alanları yer altı ve yeryüzüdür. Kahramanlar bu dünyalara ait olağanüstü yaratıklarla savaşmak ve onları alt etmek zorundadırlar. Atı, destan kahramanının en büyük yardımcısıdır.

Her destan, anlatılan kahramanın âdeta hayat hikâyesidir. Bu hikâye genellikle yaşlı bir anne babadan doğan bir çocuğun kahramanlık hikâyesini anlatır. Uzun bir bekleyişten sonra doğan çocuk kahramanlık göstererek bir isim almaya hak kazanır. Kahramanlık yaparak veya olağanüstülük göstererek evlenir. Amacı kendi ulusunun ve ailesinin düşmanlarını yok etmek ve bütün Türk kavimlerini bir imparatorluk adı altında birleştirmektir. Destan kahramanı bunu gerçekleştirebilirse amacına ulaşmış demektir (Yildırım, 2006, s. 60).

Görüldüğü üzere destan kahramanı için aşk ikinci plandadır. Dolayısıyla aktif bir yaşam içinde kocalık statüsü hakanlık statüsünden sonra gelir. Her ne kadar kahraman evlilik için çaba sarf ediyor gibi görünse de bunu gerçekleştirebilmek için de kahramanlık göstermesi, birtakım sınavlardan geçmesi, hem akıl hem de bilek gücünü ortaya koyması gerekmektedir.

Destan kahramanı, mitlerdeki tanrılar ve tanrısal güçleri ellerinde barındıranlarla gerçek hayattaki insanlar arasında köprüler oluşturmaktadır (Necatigil, 2002, s. 13). Toplumsal dinamikler ve tarih sahnesinde biraktıkları iz dikkate alındığında bazı destan kahramanlarının ön plana çıkması kaçınılmazdır. Oğuz Kağan, Gılgamış ve Manas bu örnekler arasındadır. 


\section{DESTAN KAHRAMANLARININ STATÜLERİ: YÖNETICİ KAHRAMANLARIN STATÜSÜ}

\section{Oğuz Kağan}

Oğuz Kağan'ın, yüzü gök mavisi, ağzı kıpkırmızı, benzi ateş gibidir. Gözleri al al, saçları kapkara ve kaşları perilerinkinden güzeldir. Ayakları öküz ayağı gibi, omuzu samur omuzu gibi, göğsü koca ayınınki gibidir. İnsan olmasına rağmen vücudunun hemen her yeri kıllarla kaplıdır. Anne sütünü sadece bir kez alır ve ondan sonra bir daha emmez. Pişmemiş et ve aş yemek ister. Birdenbire dile gelir ve konuşmaya başlar. Öylesine güçlüdür ki at sürülerini güder ve o atlara biner (Bang-Arat, 1988, s. 13-14).

Türklerin eski zamanlarda yaşamış, fetihte sınır tanımayan hanlarından biri Oğuz Kağan'dır. Onun fetihleri sayesinde Türkler çok geniş topraklarda hâkimiyet kurmuşlardır. Oğuz Kağan'ın altı oğlu ve yirmi dört torunu vardır. İslamiyet sonrası Oğuz Kağan anlatılarında o kavmini hak dinine sokmak için Tanrı tarafından gönderilmiş bir hükümdar olarak kabul edilir. Oğuzların tek eşli bir yaşamı tercih ettiği ve eşlerinin fikirlerine saygı gösterdikleri gibi kadınların toplumda söz sahibi olduğu da ifade edilebilir (Sümer, 1992, s. 272-273, 291).

Fiziki özellikleri anlatılan Oğuz Kağan, çizilen bu portre ile olağanüstülüğünü gösterir. İnsani özellikleri olağanüstülüklerle birleşen, toplumunu geleceğe taşıyan bir alp tipini ortaya çıkarmaktadır. Destan kahramanlarında aranan güçlü, adil, cesur ve yiğit olmak gibi temel ve çok önemli nitelikler halkın zihninde kahramanı yöneticiliğe taşıyan özelliklerdir. Oğuz Kağan’ın destan boyunca bu özellikleri taşıyan bir yönetici kahraman olduğu görülmektedir.

\section{Gilgamış}

Gılgamış, Uruk şehrinin kralıdır. Bu şehrin en görkemli tapınağı ona aittir ve bu tapınağı kendi inşa etmiştir. Gılgamış, 2/3 tanrı ve 1/3 insandır. Siyah saçları omuzlarında, sakalı ve bıyığı hafif kırlaşmış, uzun boylu, adaleli, iri gövdeli yakışıklı ve güçlüdür. Halkı,

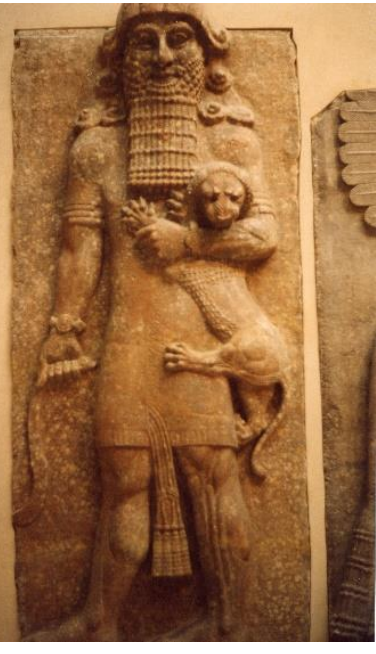
onu kendilerinden üstün ve farklı meziyetlere sahip bulduğundan onda bir tanrısallığın olduğuna inanmıştır. Annesi bilge tanrıça Nintu, babası Uruk krallığı yapmış bir ölümlü olan asil Lugalbanda'dır. Gılgamış ulu tanrıça Nintu tarafından yaratılmıştır. Bu yüzden tanrılar tarafından desteklenir. "Her şeyi gören ve bilen" demek olan Gılgamış, gerçekten de bilgili, akıllı ve yol göstericidir. Okumayı, yazmayı bilir (Çı̆̆, 2000, s. 9-10).

Genç bir kralken etrafına vahşi bir boğa kadar korku salan Gılgamış, korku nedir bilmeyen, büyük bir güreşçi ve savaşçıdır. Dua eden, yakışıklı, cesaretli, bilge bir kahraman olan Gılgamış aynı zamanda zalim bir hükümdardır. Buna rağmen o gördüklerini düşünüp yorumladığı ve amacı 
bilgiyi elde etmek olduğu için diğer kahramanlardan farklı bir özellik göstermektedir. Amacına ulaşmak için cesaretin yeterli olmadığını fark etmesi onun erdemli bir kahraman kimliği kazanmasını sağlamıştır. $O$, büyük bir azim, hırs ve tahammülle insanın ölümsüz olamayacağını öğrenmiştir. (Rosenberg, 1998, s. 262-264).

Kimi zaman insana ait zayıflıklar gösterebileceği gibi çoğu zaman toplumun da saygısını kazanmasını kolaylaştıran tanrı soylu olma özelliği Gılgamış’ın statüsünü belirleyen en önemli özelliklerinden biridir. Bu kutsiyetin yanında karizmatik bir lider portresinin çizildiği anlatıda en yakın arkadaşını kaybedince derin bir üzüntüye kapılacak kadar naif bir birey tipi de çizilmiştir. Düşünen, sorgulayan, idealinin peşinden gitmeyi tercih eden ve bu uğurda mücadeleyi göze alan Gılgamış, pek çok kişinin sahip olmak istediği özellikleri taşıdığından statü bakımından oldukça yüksek bir konumda olan yönetici kahramandir.

\section{Manas}

Manas, Kırgız Hanlarından Uruz Han'ın torunudur. Babası Yakup (Cakıp) unvanı ile anılmaktadır. Doğumundan önce Kırgızların kurtarıcısı olacağı kâhinler tarafından bildirilmiştir. On iki yaşında yedi yüz kişilik bir Çin ordusunu kumandanları ile mağlup eder. Beline saplanan demiri senelerce kimseye hissettirmeden kapanmış bir yara içinde taşır. Hilelerden kendi gücüyle kurtulur. Bir han olduğu için halkına hizmet etmek, onları rahat ettirmek çabasındadır. Bu yüzden halka musallat olan sıkıntılarla kutsal bir kişiliğe sahip olan Manas uğraşır. Halk onu bu şekilde görmüş ve kabullenmiştir. Halkı için çalışan bir hükümdar özelliği göstermektedir (Öztürk, 2000: s. 281, 284, 285).

Çeşitli olağanüstülüklere sahip bir destan kahramanı olan Manas, destanda ifade edilen soy silsilesine istinaden bir milletin soy devamlılığını sağlayan gerçek bir insan tipini yansıtmaktadır. Gücüyle hilelerden kurtulan, kendini halkına adamış, onların huzurunu önceleyen bir hükümdar olarak yüksek bir statüye erişmiştir. Uzun süren mücadelelerin sonunda galip gelen Manas, insanüstü bir çaba ve beceriye sahip olduğunu ispat etmiştir.

\section{HALK HİKÂYESİ KAVRAMI}

Hikâye kelimesi eğlendirmek amacıyla taklit anlamına gelir. Başkalarının tavır, davranış, ses ve karakterlerini biraz gülünç tarzda taklit eden kişilere hakiya denilmektedir. Gerçek hayattan alınan ve okuyucuların/dinleyicilerin bildikleri maceralar ve konular anlatılır (Alptekin, 2016, s. 15).

İslam medeniyetinin etkisi Türkler arasında tam olarak yerleşmeden önce halk hikâyelerini anlatma görevi ozanlarındır. Kopuzu eşliğinde diyar diyar dolaşarak eski menkıbevi kahramanların hikâyelerini anlatan bu ozanların adları, İslam kültürünün etkisiyle âşık-saz şairi olarak değişmiştir. Bir kısmı yüksek zümrelere hitap etmekle beraber 
klasik tahsil gören nedimlere, kıssahan veya meddah denilmiştir. Hikâye anlatıcıları olan meddahlar, meddah olarak anılmadan önce Araplarda kussas ve Acemlerde kıssa-han olarak bilinmişlerdir. $\mathrm{Bu}$ anlatı türü, İran hikâye anlatma geleneğinin devamı niteliğindedir (Köprülü, 2004, s. 318-320, 327).

Meddah ile âşık arasındaki en önemli farklardan biri, meddahın tavrında dramatik izler olmasına karşılık, âşığın sanatında epik tür özelliklerini yansıtmasıdır. Meddah, dinleyicileri etkisi altına alır ve dinleyicileri hikâyenin içine çeker, âşık söylediği türküler ve deyişlerle dinleyicileri gerçek hayata yaklaştırır. Halk hikâyeleri olayları ve kişileri idealleştirirken meddah hikâyelerinde gerçekçi bir yaklaşımla karşılaşılır. Meddah hikâyelerinde anlatıcı birden çok kişinin taklidini yapmak zorundadır. Buna karşılık halk hikâyesi anlatıcısının böyle bir kaygısı yoktur. Ancak o da hikâyeyi süsleyecek açıklamalar yapar (Nutku, 1997, s. 64, 75). Bu gelenek uzun yıllar sürmesine rağmen destandan halk

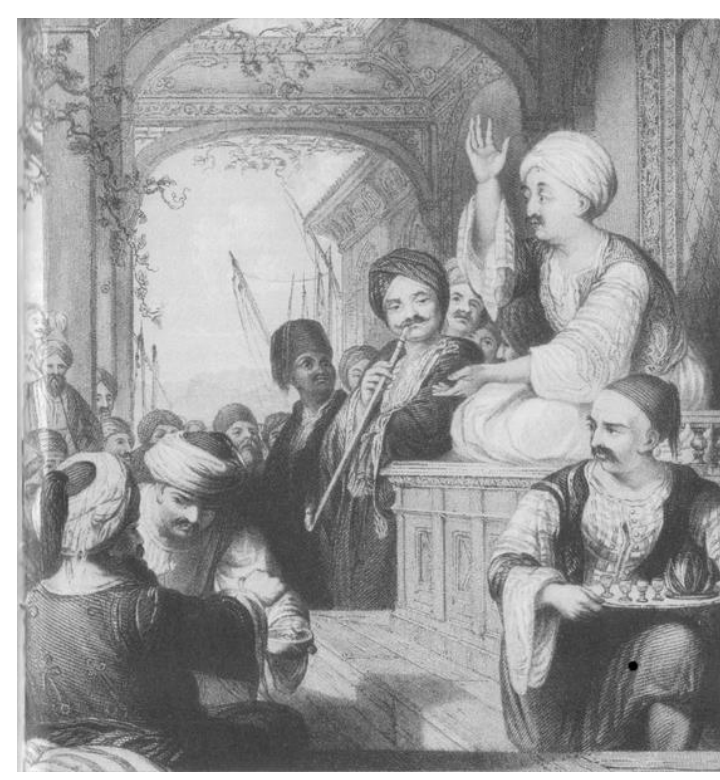
hikâyesine geçişin tarihi XVI. asırdaki tarihi belgelerin yetersizliğinden tam olarak bilinmemekle beraber Yıldırım Bayezid, II. Murat, Fatih Sultan Mehmed'in saltanatları süresince saraylarında kıssahanların bulunduğundan söz edilmekte ancak meddahların isimleri zikredilememektedir. Evliya Çelebi'nin Seyahatnamesi'nden öğrenilen bilgilere göre XVII. yüzyılda da meddah ve kıssahanlar varlıklarını korumaktadırlar (Köprülü, 2004, s. 328-332).

Yeni ve farklı bir çeşit özelliği gösteren halk hikâyeleri bununla birlikte destan türünün niteliklerinin birçok özelliğini korumaya devam etmiştir. Zaman içinde sosyal şartların etkisiyle destan söyleme geleneği yerini hikâye anlatma geleneğine bırakmıştır (Boratav, 1988, s. 63). Halk hikâyeleri, kahramanlık ve aşkın bir kahraman etrafında anlatıldığ1 türlerdendir. Edebi ve estetik açıdan taşıdığı motiflerle geçmişten günümüze kültürel yönden bağlar kurarak âşık tarzı şiir geleneği ve müziği, tahkiye geleneği ve meddahlık geleneğinin taşıyıcısı konumundadır (Çelepi, 2015, s. 157). Bu özellikler bütünüyle değerlendirildiğinde halk hikâyelerinde insanlık âlemi açısından en önemli ve temel gereksinimlerden biri olan aşka büyük ölçüde yer verildiği görülmektedir. Dünyayı anlama, oluşum ve dönüşümleri açıklama çabalarının ardından destan çağında kendine bir yurt arayan kahraman, temel ihtiyaçlarını tamamladıkça insani duygu ve düşüncelere anlatılarda daha geniş ölçüde yer vererek dinleyicide/okuyucuda estetik bir haz da uyandırmıştır. Bu hazzın yükselebilmesi metinde yer alan engel ve oyunların gerçekçi olması ve dolayısıyla 
anlatılan kahramanların statüleriyle yakından ilgilidir. Kahramanların özellikle ailelerine bağlı statüleri söz konusu anlatılarda meydana gelen gerilimin yapı taşını oluşturmaktadır.

\section{HALK HİKÂYESİ KAHRAMANLARININ STATÜLERİ: BİREY KAHRAMANLARIN STATÜSÜ}

Halk hikâyelerinde kahramanların statüleri değerlendirilirken mitik dönemden halk hikâyesine geçiş sürecinde bireyselleşmenin yaşandığı görülür. Bununla beraber kahramanın ailesi ve yakın çevresiyle olan bağları, statünün belirlenmesinde temel bir rol üstlenmektedir.

Halk hikâyelerinde yer alan kahramanların statüleri 'verilmiş' ve 'kazanılmış' olmak üzere iki başlık altında değerlendirildiğinde verilmiş statünün kahramanın yaşamının yönlendiricisi konumunda olduğu, özellikle sevdiği kişi ile evlenebilme noktasında ailelerin statülerinin önem kazandığı görülmektedir (Çelepi, 2015, s. 168). Bu bağlamda kahramanlar statüleri belirlenirken ailelerinden bağımsız düşünülmemelidir. Aileler de başlı başına bir birey gibi toplumda kendi özellikleri bağlamında bir yer bulmaktadır. Günümüzde de bireyler, toplumda belirli ve tanımlı olabilmek, statülerini ifade edebilmek için kendilerini taşıdıkları 'soyad'larıyla aile ve sülalelerine bağlı tutmaktadırlar.

\section{Kerem ile Aslı Hikâyesi}

Hikâyenin yazma, basma nüshaları, çeşitli rivayetleri, Kerem tiyatroları bulunmaktadır (Elçin 2000, 11-12). Bu çalışmada yazma nüshaya göre değerlendirme yapılmıştır. Kerem ile Aslı hikâyesinde kahramanların hayatlarıyla sosyal çevre arasındaki ilişkilerden hareketle yaşanılan hayata geçmek mümkündür. Hikâye her ne kadar bilinmeyen bir zamanda geçse de işlediği konu itibariyle tüm zamanları ilgilendirir (Elçin, 2000, s. 32).

\subsection{Kerem}

Hatice Sultan ve Sururi Şah'ın oğullarıdır. Uzun yıllardan sonra bir dervişin keramet göstermesiyle dünyaya gelmiştir. Babasının Keşiş Yahud'a verdiği sözle doğduğu günden itibaren Aslı'nın kısmetidir. Gerçek adı 'Şah Gülşen'dir. On beş yaşında kâmil olan Şah Gülşen bu zamana kadar hocası Sofu tarafından eğitilir. Hikâyede 'dolu' içme, Kerem'in Aslı'yı görüp bayılmasıyla olur. Kerem, Aslı'ya âşık olur. Ancak Aslı, Kerem’in duası sonucu Kerem'e âşık olur. Rüyasında 'bade' içen Kerem şiir söylemeye başlar. Aslı'ya kavuşabilmek için çeşitli engelleri aşar (Elçin, 2000, s. 12-15, 18). Zengin ve adaletli bir padişahın oğlu olan Kerem, bilgi, zekâ ve muhayyilesini geliştiren bir ortamda gençlik çağına girince babasının karşı çıkmasına rağmen sevgilisi için rahatını, malını, huzurunu terk ederek yola çıkar.

Saz şairliğinin esaslarından biri seyahat, diğeri ise şiir söylemektir. Kerem aşkı için her türlü kazanımını geride bırakarak halkın gönlünü fethetmeyi başarmıştır (Elçin, 2000, s. 3233). Kolay kazanılan hiçbir şey, halkın gözünde değerli değildir. Bir kişinin birey olabilmesi, toplumda söz ve statü sahibi olmasının belirleyicisi, zorlukları veya engelleri aşmaktaki 
çabası ve istikrarıdır. Halk hikâyelerindeki kahramanların durumu halkın düşüncelerinin yansıması olarak düşünülmelidir.

\subsection{Asl1}

Şiraz şehrinde yaşayan Aslı bir keşiş olan Yahud'un güzeller güzeli kızıdır. Bir derviş sayesinde uzun yıllardan sonra dünyaya gelmiştir. Asıl adı Meryem'dir. Babasının Sururi Şah'a verdiği sözle doğdukları günden itibaren Kerem'in kısmetidir. Kerem'in duasıyla rüyasında bade içer ve Kerem'e duyduğu aşk alevlenir (Elçin, 2000, s. 12-15).

Doğumlarından itibaren bir olağanüstülük gösteren kahramanlar, bu farklılıklarını Kerem'in duasının kabul olmasıyla da sürdürmüşlerdir. Türk kültüründe önemli bir yere sahip olan saz şairliğinin temelleri bir kutsiyet etrafında ve inanç çerçevesinde Orta Asya'dan Anadolu'ya taşınmıştır. Şiir söyleme yeteneğinin dua sonucu Aslı tarafından kazanılması bu durumun ispatı niteliğindedir.

\subsection{Kahramanların Aileleri}

Biri şah oğlu biri de Keşiş kızıdır. Şahlık idari anlamda keşişlik de dini anlamda sosyal statüyü belirleyen önemli görevlerdir. Her ikisi de toplumda itibar gören kişilerdir. Aralarında akrabalık yoktur ancak her ikisi de çocuklarını geç elde ettikleri için beraber olmalarını dilerler ve bunun için sözleşirler. Hikâyenin başında bu statü farkı âşıkların kavuşmasını engeller ancak halkın gönlü onların kavuşmasından yanadır.

\section{Tahir ile Zühre Hikâyesi}

Tahir ile Zühre hikâyesinin Anadolu ve Anadolu sahası dışındaki Türk boylarında ve Türklerle kültürel bağları bulunan diğer milletlerde sözlü, yazma ve matbu kaynaklarda pek çok eş metni bulunmaktadır (Türkmen, 1998, s. 5).

\subsection{Tahir}

Bir vezir oğludur. Uzun yıllar sonra bir derviş duasıyla dünyaya gelir. Adı bile derviş tarafından belirlenmiştir. İleride sevgilisi olacak olan Zühre'yle aynı sarayda büyürler. On yaşına kadar birbirlerini kardeş zannederler. Tahir akıllı, yakışıklı ve güçlü bir yiğittir. İyi bir eğitim almıştır. Zühre'ye kavuşabilmek için zindanlarda kalmayı göze alır. Hatta kadın kılığına bile girer. Tahir aynı zamanda bir ozandır. Usta-çırak ilişkisiyle saz çalmayı öğrenir (Türkmen, 1998, s. 209-249).

Tahir, gerek ifade edilen fiziki özellikleri gerekse aldığı eğitim, sahip olduğu ailenin konumu vb. gibi nedenlerle statü bakımından yüksek bir konumdadır. Sevdiği için her türlü engeli aşabilecek gücü kendinde bulan kahraman, saz çalmayı öğrenen bir ozan oluşuyla toplumun zihninde ait olduğu konumu inanç temelli bir kutsiyet etrafında pekiştirmiştir. Tahir, destandan halk hikâyesine geçiş sürecinde alp tipinin âşık tipiyle birleştiği bir kahraman olarak görülmektedir. 


\subsection{Zühre}

Padişahın uzun yıllardan sonra derviş duasıyla doğan kızıdır. Çok güzel bir kızdır. Tahir'le aynı sarayda büyür ve birlikte eğitim alırlar. Uzun yıllar ayrılık hasreti çeker ancak Tahir'e duyduğu sevgi azalmaz. O da şiir söyleme yetisine sahiptir ve bir ustadan saz çalmayı öğrenir (Türkmen, 1998, s. 209-249).

Tahir'le hemen hemen aynı özelliklere sahip olan Zühre, Tahir gibi aşkına sahip çıkan ve destandan halk hikâyesine geçiş sürecinin özelliklerini sürdüren bir kadın tipi olarak görülmektedir. Sevdiğine kavuşabilmek için benzer zorluklara göğüs gerer, bu engelleri aşmak için çabalar, sevdiğinden vazgeçmez. Kahramanın zoru aşması veya engelleri aşabilmek için gösterdiği çaba, toplumun bakış açısının ve hayatı anlamlandırma çabasının bir tezahürü olarak değerlendirilebilir. Kahramanın kadın veya erkek olmasından ziyade mücadeleci bir ruha ve ruhun özelliklerine sahip olmasının statüyü belirleyen asıl unsurlardan biri olduğu söylenebilir.

\subsection{Kahramanların Aileleri}

Tahir ve Zühre'nin babalarının pek çok eş metinde kardeş veya statü bakımından yüksek bir mevkide gösterilmesi hikâyede gerilimin artmasına neden olmaktadır. Bazı eş metinlerde Tahir'in hayatının kurtulmasına, pek çok eş metinde de 'söz kesme' ritüelinin gerçekleşmesine yardımcı olacaktır. Eş metinlerin hemen hepsinde Zühre'nin babası aristokrat bir zümreden, Tahir'in babası da Zühre'nin babasından hemen sonra gelen sosyal bir statüye sahiptir (Türkmen, 1998, s. 32-33).

Zühre, padişah kızı ve Tahir de vezir oğludur. Her ikisi de aynı şartlarda büyümelerine rağmen statü devreye girer ve bir kölenin ortalığı karıştırmasıyla Tahir ve Zühre'nin aileleri, onların birleşmelerine engel olur. Ailelerin zihninde bir padişah kızı ancak bir padişah oğluna layıktır. Fakat buna rağmen sevgililer birbirlerinden vazgeçmezler. Çünkü onlar bu dünyada olmasa bile öteki dünyada mutlaka birlikte olabileceklerini düşünürler.

\section{Ferhat ile Şirin Hikâyesi}

\subsection{Ferhat}

Horasan'ın meşhur boyacısı Behzad'ın nakkaş olan oğludur. On beş yaşlarında, son derece hünerli ve yakışıklı olan uzun boylu, geniş omuzlu, ince belli, gür kaşları olan bir delikanlıdır. Şirin'in yüzünü bir kere görerek âşık olması onun için dağları delmesine yeter. Ferhat, Şirin'e kavuşabilmek için her türlü zorluğa katlanır. Onda da ozanlık yetisi vardır. Ayrıca Ferhat'ın kutsî bir yanı vardır. Mühmine Hatun, Ferhat'ı gördüğü rüya sonucu serbest birakır (B.N, 1982, s. 3-48). 
Ferhat da diğer halk hikâyesi kahramanlarının pek çoğunda olduğu gibi fiziki özellikleri itibariyle yakışıklı ve yetenekli bir kişi olarak tanıtılmıştır. Aşkı için engelleri aşmasının yanında ozanlık yetisine sahip olması Ferhat'a da yüksek bir statü kazandırmıştır.

\section{2 Şirin}

Horasan eyaletinin bir köşesinde bulunan büyük bir şehrin melikesi olan Mühmine Banu'nun yeğenidir. Güzelliği dillere destandır. Kaşları keman, kirpikleri âdeta bir ok, on dört yaşlarında güzeller güzeli bir kızdır. Ferhat'ı bir kez görür ve ona tüm kalbiyle âşık olur. Ferhat'a derdini anlatabilmek için şiir söyler (B.N, 1982, s. 3-48).

Şirin, adıyla müsemma bir güzeldir. Ferhat'1 görür görmez âşı olup ona ulaşabilmek, haberleşebilmek için şiir söyler. Bu hikâyede gerilimi yaratan esas unsur, Şirin'in bir melike olan Mühmine Banu'nun yeğeni olmasından kaynaklanan statü farkıdır.

\subsection{Kahramanların Aileleri}

Bu hikâyede Ferhat sıradan birinin oğlu, fakir bir nakkaş, Şirin ise bir melikenin yeğeni, sultan ve zengindir. Âşıklar birbirlerini türlü cefalara katlanacak kadar sevmelerine rağmen bu statü farkı onlar için ciddi bir engeldir. Aileleri akraba değildir ve maddi olarak birbirlerine denk değillerdir. Bu hikâyede âşıkların durumunun neredeyse temel belirleyicisi ailelerinin statüleridir.

\section{SONUÇ}

Mitlerde karşımıza bir kutsallık çerçevesinde çıkan tanrı kahramanlar bilge, cesaretli, güçlü, sabırlı, erdemli ancak kimi zaman kıskançlık, nefret, kin gibi duygularla kimi zaman da aldatma, eziyet etme ve öç alma şeklindeki insani zayıflıklarla görülmektedirler.

Destan kahramanları belli tanrısal özellikleri ya soylarında ya da benliklerinde barındırmakla beraber birçok olağanüstülüklere de sahip genellikle insan veya kimi zaman da tanrısal özelliği olan insan ve yönetici kahramanlardır. Bu kahramanlar güçlü, iradeli, zeki, bir topluluk üzerinde hâkimiyet kurabilen karizmatik kişilerdir. Ayrıca yaşam biçimleri ve coğrafyaları da tanrılardan farklıdır.

Halk hikâyelerindeki kahramanlar insandır. Bireyselleşme sürecini yansıtan kahramanlar aşkın ve sevginin peşindedir. Birey kahramanlar, çoğu zaman akıl, bilek ve yürek gücünü birleştirerek; ellerindeki sazları, dilindeki şiirleri hislerine tercüman olarak kullanmış ve aşkları için her türlü tehlikeyi göze almışlardır. Buna karşılık destanlarda yer alan kahramanlar yaşam koşullarının etkisiyle aşka daha az yer ayıran hareketli ve savaşçı bir kimlik kazanırlar.

Anlatıma dayalı olan bu türler genel itibariyle değerlendirildiğinde kahramanlar, kronolojik sırayı takiben mekân olarak gökyüzünden yeryüzüne inmişlerdir. Mitlerde tanrılar genellikle gökyüzünü kendilerine mesken tutarlarken, halk hikâyesindeki 
kahramanlar yeryüzünü tercih ederler. Bu noktada destan kahramanları bir geçiş dönemi özelliği gösterirler. Destan kahramanları yeryüzünde yaşarlar ama aynı zamanda da tanrısal bir gücü bünyelerinde barındırırlar. Bu yüzden 'gök'le olan bağları kuvvetlidir.

Böylelikle hem mekân hem de güç ve irade kullanımı açısından incelenen mit, destan ve halk hikâyeleri arasında bu bağlamda bir farklılık görülmektedir. Yaşam standartları ve koşulları kahramanları birtakım kutsiyetlerden uzaklaştırmadan insanileştirmiş, Tanrı kahramanlardan birey kahramanlara dönüştürmüştür.

\section{KAYNAKÇA}

Alptekin, Ali Berat (2016). Halk Hikâyelerinin Motif Yapısı. Ankara: Akçağ Yayınları.

Bang,W.-R.Rahmeti Arat (1988). Oğuz Kağan Destanı (yay. haz. Muharrem Ergin). Ankara: Hülbe Basım ve Yayın A.Ş.

B.,N. (1982). Ferhat ile Şirin. İstanbul: Şenyıldız Yayınevi.

Bıçak, Ayhan (2012). Evren Tasavvuru Kendini Bilmek ya da Evreni Kurmak. İstanbul: Dergâh Yayınları.

Bonnefoy, Yves (yönetmen) (2000). Antik Dünya ve Geleneksel Toplumlarda Dinler ve Mitolojiler Sözlüğ̈̈u. (çev. Levent Yılmaz). Ankara: Dost Kitabevi.

Boratav, P.Naili (1988). Halk Hikâyeleri ve Hikâyeciliği. İstanbul: Adam Yayınları.

Çelepi, Mehmet Surur (2015). “Halk Hikâyelerinde Aşk ve Statü". Türkmen Bilgesi Fikret

Türkmen Armağanı (ed. İbrahim Dilek-Ferah Türker). Ankara: Türk Kültürünü Araştırma Enstitüsü Yayınları, s. 157-170.

Çı̆̆, Muzaffer İlmiye (2000). Gılgameş-Tarihte İlk Kral Kahraman-. İstanbul: Kaynak Yayınları. Çoruhlu, Yaşar (2010). Türk Mitolojisinin Ana Hatları. İstanbul: Kabalcı Yayınları.

Demir, Ömer ve Mustafa Akar (2005). Sosyal Bilimler Sözlüğ̈̈. Ankara: Adres Yayınları.

Elçin, Şükrü (2000). Kerem ile Aslı Hikâyesi (Araştırma-İnceleme). Ankara: Akçağ Yayınları.

Eliade, Mircea (1993). Mitlerin Özellikleri (çev. Sema Rifat). İstanbul: Simavi Yayınları.

Eliade, Mircea (2014). Dinler Tarihine Giriş (çev. Lale Arslan Özcan). İstanbul: Kabalcı Yayınları.

Erhat, Azra (2003). Mitoloji Sözlüğ̈̈̈. İstanbul: Remzi Kitabevi.

Fink, Gerhard (1997). Antik Mitolojide Kim Kimdir (çev. Ümit Öztürk). İstanbul: Kabalc1 Yayınevi.

Hamilton, Edith (2002). Mitologya (çev. Ülkü Tamer). İstanbul: Varlık Yayınları.

İnan, Abdülkadir (2006). Tarihte ve Bugün Şamanizm-Materyaller ve Araştırmalar-. Ankara: Türk Tarih Kurumu Yayınları.

Köprülü, M. Fuat (2004). Edebiyat Araştırmaları 1. Ankara: Akçağ Yayınları.

Marshall, Gordon (1999). Sosyoloji Sözlüğ̈̈̈. Ankara: Bilim ve Sanat Yayınları. 
Nutku, Özdemir (1997). Meddahlık ve Meddah Hikâyeleri. Ankara: Atatürk Kültür Merkezi Başkanlığı Yayınları.

Ögel, Bahaeddin (1993). Türk Mitolojisi. C.I. Ankara: Türk Tarih Kurumu Basımevi.

Önal, Mehmet Naci (2009), “Kutsalın Türk Kültüründeki İzleri: Tanrısal Simgecilik”. Millî Folklor, S. 84, s. 57-72.

Öztürk, Ali (2000). Çă̆ları İçinde Türk Destanları. İstanbul: Alioğlu Yayınevi.

Rosenberg, Donna (1998). Dünya Mitolojisi-Büyük Destan ve Söylenenler Antolojisi- (çev. Koray Atken vd.). Ankara: İmge Kitabevi.

Seyidoğlu, Bilge (1995). Mitoloji Üzerine Araştırmalar-Metinler ve Tahliller-. Kayseri.

Sümer, Faruk (1992). Oğuzlar (Türkmenler) Tarihleri- Boy Teşkilatı- Destanları. İstanbul: Türk Dünyası Araştırmaları Vakfı.

Necatigil, Behçet (2002). 100 Soruda Mitologya. İstanbul: Gerçek Yayınevi.

Türkçe Sözlük (2005). Ankara: Türk Dil Kurumu Yayınları.

Türkdoğan, Orhan (1999). “Türk Destanlarında Millî Kültür Kalıpları”. İstanbul: Türk Edebiyatı, S. 303.

Türkmen, Fikret (1998). Tahir ile Zühre (İnceleme-Metin). Ankara: Atatürk Kültür Merkezi Başkanlığı Yayınları.

Uraz, Murat (1994). Türk Mitolojisi. İstanbul: Düşünen Adam Yayınları.

Yıldırım, Dursun (2006). "Türk Kahramanlık Destanları", İslamiyet Öncesi Türk Destanları (haz. Prof. Dr. Saim Sakaoğlu- Prof. Dr. Ali Duymaz). İstanbul: Ötüken Yayınları.

Yıldız, Naciye (1995). Manas Destanı (W. Radloff) ve Kırgız Kültürü ile İlgili Tespit ve Tahliller. Ankara: Türk Dil Kurumu Yayınları.

Yörükan, Turhan (2000). Yunan Mitolojisinde Aşk. Ankara: İş Bankası Kültür Yayınları. 